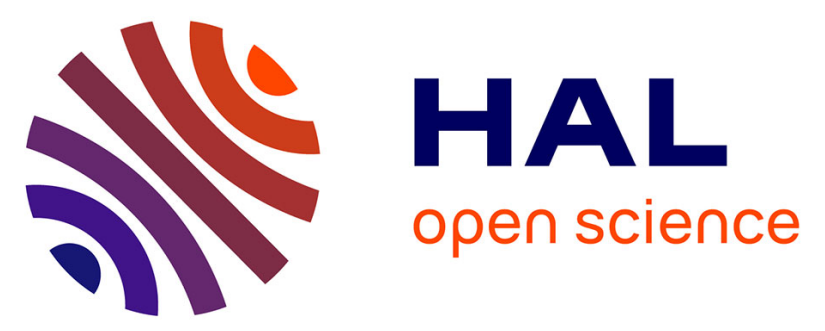

\title{
Protein and mineral nutrient contents in kernels from 72 sweet almond cultivars and accessions grown in France, Greece and Italy
}

Pavlina D. Drogoudi, Georgios Pantelidis, Loretta Bacchetta, Donato de Giorgio, Henri Duval, Ioannis Metzidakis, Daniella Spera

\section{To cite this version:}

Pavlina D. Drogoudi, Georgios Pantelidis, Loretta Bacchetta, Donato de Giorgio, Henri Duval, et al.. Protein and mineral nutrient contents in kernels from 72 sweet almond cultivars and accessions grown in France, Greece and Italy. International Journal of Food Sciences and Nutrition, 2013, 64 (2), pp.202-209. 10.3109/09637486.2012.728202 . hal-02651820

\section{HAL Id: hal-02651820 \\ https://hal.inrae.fr/hal-02651820}

Submitted on 29 May 2020

HAL is a multi-disciplinary open access archive for the deposit and dissemination of scientific research documents, whether they are published or not. The documents may come from teaching and research institutions in France or abroad, or from public or private research centers.
L'archive ouverte pluridisciplinaire HAL, est destinée au dépôt et à la diffusion de documents scientifiques de niveau recherche, publiés ou non, émanant des établissements d'enseignement et de recherche français ou étrangers, des laboratoires publics ou privés. 


\title{
Protein and mineral nutrient contents in kernels from 72 sweet almond cultivars and accessions grown in France, Greece and Italy
}

\author{
PAVLINA D. DROGOUDI ${ }^{1}$, GEORGIOS PANTELIDIS ${ }^{1}$, LORETTA BACCHETTA $^{2}$, \\ DONATO DE GIORGIO ${ }^{3}$, HENRI DUVAL ${ }^{4}$, IOANNIS METZIDAKIS ${ }^{5}$, \& DANIELLA SPERA ${ }^{6}$ \\ ${ }^{1}$ Pomology Institute, Hellenic Agricultural Organization 'Demeter', DG of Research, NAGREF, Naoussa, Greece, ${ }^{2}$ Italian \\ National Agency for New Tecnologies Energy and Sustainable Economic Development, Casaccia, Rome, Italy, ${ }^{3}$ Consiglio per la \\ Ricerca e Sperimentazione in Agricoltura Unità di Ricerca per i Sistemi Colturali degli Ambienti caldo-aridi, Bari, Italy, ${ }^{4}$ Institut \\ National de la Recherche Agronomique, INRA GAFL, Montfavet Cedex, France, ${ }^{5}$ Institute for Olive Tree and Subtropical Plants, \\ Hellenic Agricultural Organization 'Demeter', DG of Research, NAGREF, Chania, Greece, and ${ }^{6}$ Consorzio di Ricerche Applicate \\ alla Biotecnologia, Avezzano, Italy
}

\begin{abstract}
Almond protein and potassium $(\mathrm{K})$, phosphorus $(\mathrm{P})$, calcium $(\mathrm{Ca})$ and magnesium $(\mathrm{Mg})$ contents were determined in 72 cultivars and accessions grown in France, Greece and Italy, as part of the networking of European SAFENUT AGRI GEN RES project, which aimed to explore and valorize the almond genetic resources in Europe. Great variation was found in the nutrient content and the amount of nutrient supplied when consuming the recommended daily amount of one serving of almond, among the different genotypes assayed. The variation among the different genotypes was greatest for Ca, followed by the protein content; the latter also exhibited the lowest variation considering the harvest year. Results from a principal component analysis showed that $\mathrm{P}$ and $\mathrm{Mg}$ were the most discriminant elements for categorizing samples. Cluster analysis showed groups of samples with interesting characteristics for breeding. There was no clear distinction among the different origins of samples. Correlation analyses between weather conditions and the nutrients assayed showed that the mean temperature recorded in the period between March and September was positively correlated with $\mathrm{Ca}$ and P only in France, a place where the greatest climatic difference between years was observed.
\end{abstract}

Keywords: environment, genetic resources, mineral nutrient, protein, sweet almond

\section{Introduction}

Sweet almond (Prunus dulcis M.) is one of the oldest cultivated fruit species and was appraised for its culinary uses and its numerous medicinal properties. The ancient Greek doctors Hippocrates and Galen ascribed to almond characterizations such as 'hot', 'heating', 'cleansing', 'nourishing' and 'strengthening mental functions' (Albala 2009). Recent medical research has shown that almond consumption has been associated with a wide range of health benefits, including reduced levels of coronary heart disease as a result of reduction in the low density lipoprotein (LDL)-cholesterol, hypertension, type 2 diabetes, obesity and reduction in oxidative stress (Chen et al. 2006). The nutritional properties of almonds are due to their components such as lipids and unique fatty acids (containing mostly unsaturated fat, little saturated fat and no cholesterol), total fibre (containing small amounts of viscous fibre), protein, arginine, $\alpha$-tocopherol, magnesium, copper, manganese, calcium, phosphorus and potassium (Chen et al. 2006; Yada et al. 2011). The high contents of macronutrients make almond an important dietary source for these essential elements. Almond is considered as a 'nutrient-dense' nut, meaning that it provides a variety of nutrients in high amounts per serving and because it is minimally processed and contains minimal solid fat, sugars, starches or sodium (United States Department of Agriculture (USDA) 2005). Moreover, approxi-

Correspondence: Pavlina D. Drogoudi, Pomology Institute, Hellenic Agricultural Organization 'Demeter', DG of Research, 38 R.R. Station, 59035 NAGREF, Naoussa, Greece. Tel: + 3023320 41548. Fax: + 302332041178.

E-mail: drogoudi@otenet.gr 
mately $15 \%$ of energy in almonds is from proteins, which are of high quality, because of their unusually high content in arginine that positively affects digestibility (Ahrens et al. 2005).

The composition and characterization of macroand micronutrients present in cultivated almond cultivars have been reviewed by Yada and colleagues (2011). The almond genotype was documented to have an important role in almond protein and mineral nutrient content in cultivars grown in California (Ahrens et al. 2005; Venkatachalam and Sathe 2006), Italy (Ruggeri et al. 1998), Spain (Saura-Calixto et al. 1981; Saura-Calixto and Cañellas 1982; Riquelme et al. 1985; Prats-Moya et al. 1997), India (Kumar and Sharma 2005), Tunisia (Ayadi et al. 2006) and Turkey (Aslantas et al. 2001). However, the majority of studies refer to widely cultivated cultivars, and little information is available for local almond cultivars (García-López et al. 1996; Aslantas et al. 2001). Nowadays, although a large number of cultivars are available, only few are widely cultivated because they possess superior agronomic characteristics such as late flowering, self-compatibility and good physical traits. Information on the nutritional characteristics of local almond varieties would be interesting from a nutritional aspect in order to depict the natural variability and elaborate the most nutrient-dense almond varieties. In the frame of the networking SAFENUT AGRI GEN RES Action activities morphological, molecular, lipid, phenolic, protein and mineral content characterization were made on the almond genetic resources in European countries with the aim to increase the knowledge and to improve its utilization by stakeholders and breeders.

The aims of this study were to (i) determine the variability and check for possible differences in protein and mineral nutrient content in various commercial cultivars and local accessions of almond which were sampled from ex situ collection orchards, or in situ, in France, Greece and Italy; (ii) select genotypes with high quality characteristics with the use of principal component analysis (PCA) and cluster analysis and (iii) evaluate the influence of harvesting year and growing region in the nutrient contents.

\section{Materials and methods}

The protein, $\mathrm{K}, \mathrm{P}, \mathrm{Ca}$ and $\mathrm{Mg}$ contents were analysed in almond kernel from 72 accessions/cultivars grown in France, Greece and Italy during 2008 and 2009. Thirty cultivars/accessions were analysed during both years, and another 42 accessions were analysed only in the second experimental year. Samples from France were the cultivars 'Ferraduel', 'Ferragnes', 'Ferrastar' and 'Lauranne', and were collected from a commercial orchard in Nîmes. Samples from Greece were 11 ecotypes or improved cultivars located in Northern Greece ('Alkion', 'Drepanoto', 'Truoito', 'Opsi- manthis Volou' and 'Raptopoulou' in a collection orchard at NAGREF, Naoussa; 'Siatista 1, -2, -3 and -4 ' in Siatista; 'Rachia' in Imathia; 'Sfendami' in Katerini), four ecotypes located in central Greece ('Babatsiko', 'Bellou' and 'Retsou' in Magnisia; 'Afrata Chiou' in the island Chios) and 10 ecotypes located in the island Grete ('Athalia', 'Lakoniotika' and 'Sitia 2, -3' in Neapoli, east-Grete; 'Temen 1' and 'Kandanos 1, -2, -3, -4' in Kandanos, west-Grete; 'Stone Almond' in Vlatos, west-Grete). Samples from Italy were 12 cultivars located in a collection orchard at CRA-SCA, Bari ('Cristomorto', 'Ferrante', 'Filippo Ceo', 'Fragiulio', 'Gaglano', 'Giunco di Cozze di Alberobello', 'Montrone', 'Riviezzo', 'Santoro', 'Senz'arte', 'Tenente' and 'Tuono'), and 31 local genotypes named with codes, located in two collection orchards in Abruzzo.

Almonds in shell were collected by hand at commercial maturity from four trees per cultivar, dried in an oven at $70^{\circ} \mathrm{C}$, and a sample of about $1 \mathrm{~kg}$ was packed and transferred by courier to the Pomology Institute in Naoussa, Greece, where analyses were carried out. Immediately before analyses each sample was manually cracked and shelled. About $200 \mathrm{~g}$ of dehulled almonds was powdered using a household mill (Kenwood, 450 W, Kenwood Limited, Hampshire, UK) for homogeneity. Samples were stored in an airtight bag at $4^{\circ} \mathrm{C}$ until further use.

For the determination of the total protein content, the Kjeldahl method (titration with $\mathrm{HCl}$ ) was used. Briefly, three replicates of $0.5 \mathrm{~g}$ of finely ground nut sample were digested with $25 \mathrm{ml}$ of $\mathrm{H}_{2} \mathrm{SO}_{4}$ and one tablet $\left(3.5 \mathrm{~g}\right.$ ) of $\mathrm{CuSO}_{4}$. The total protein content was calculated as the amount of total $N$ determined multiplied by the specific nitrogen-to-protein conversion factor of 5.18 (Association of Official Analytical Chemists [AOAC] 1995).

For the determination of the mineral contents, three replicates of about $0.5 \mathrm{~g}$ of finely ground nut were dried at $70^{\circ} \mathrm{C}$ for 2 days, and transferred to polytetrafluoroethylene vessels in which $10 \mathrm{ml}$ of $65 \%$ nitric acid $\left(\mathrm{HNO}_{3}\right)$ was added. Digestion was performed in a microwave oven (model QWAVE 4000, Questron Technologies Corp.) using the following procedure: temperature was increased at $110^{\circ} \mathrm{C}$ in $5 \mathrm{~min}$ maintained at $110^{\circ} \mathrm{C}$ for $5 \mathrm{~min}$ and at at $120^{\circ} \mathrm{C}$ for $5 \mathrm{~min}$. The digest was diluted to $50 \mathrm{ml}$ with deionized water prior to analyses.

Mineral contents were determined in Inductively Coupled Plasma Optical Emission Spectroscopy (ICP-OES) (OPTIMA 2100 DV, Perkin Elmer, Wellesley-MA, USA), equipped with an autosampler and assisted by a computer for data acquisition and readout system. The instrumental operating parameters are shown in Table I. Minerals were quantified on the basis of peak areas and compared with a calibration curve' obtained with corresponding standards. 
Version définitive du manuscrit publiée dans / Final version of the manuscript published in :

International Journal of Food Sciences and Nutrition (2012), Vol. 64, N.2, p. 202-209

DOI: 10.3109/09637486.2012.728202

Journal homepage: http://informahealthcare.com

Statistical analyses

Nutrient data were compared among genotypes and harvesting years by one-way analysis of variance (ANOVA) based upon genotype, or two-way multivariate analysis of variance (MANOVA) based upon genotype and year, and least significant difference (LSD) values were calculated in cases that significant variance was found at $p \leq 0.05$. Pearson's correlation analysis was carried out. PCA was applied to nutrient data that had been autoscaled to unit variance, and single linkage cluster analysis was carried out using the method of squared Euclidean distance on two factors produced after PCA (uncorrelated factor scores). Statistical analyses were carried out using SPSS 13.0 (SPSS Inc., Chicago, Illinois, USA).

\section{Results and discussion}

The aim of this study was to find possible differences among a large and diverse almond source of genotypes from different sites, although climatological and growing conditions differ. The minerals examined in this study ( $\mathrm{K}, \mathrm{P}, \mathrm{Ca}$ and $\mathrm{Mg}$ ) were thought to be important minerals due to their abundance and perceived health effects (AOAC 1995). Next to Ca, $\mathrm{P}$ forms the structure of teeth, bones and cell membranes. Calcium, $\mathrm{K}$ and the absence of $\mathrm{Na}$ in almonds may favourably affect total dietary levels of these nutrients and work in coordination to decrease cardiovascular disease (CVD) risks, specifically hypertension (Ros 2010; Yada et al. 2011). Finally, $\mathrm{Mg}$ has been inversely associated with several cardiovascular risk factors, including hypertension, coronary artery disease and cardiac arrhythmias, as reviewed by Champagne (2008).

Significant differences were observed between protein and mineral composition of the 72 almond genotypes assayed $(p<0.001)$ (Table II). The protein content varied 3.0 times, ranging from 9.6 to $28.5 \mathrm{mg} / 100 \mathrm{~g}$ fresh weight $(\mathrm{FW})$. The majority of samples $(93 \%)$ were in the range of 15.1 and $25.9 \mathrm{mg} / 100 \mathrm{~g}$, and greatest values were found in 'Siatista 4', 'Truoito' and 'Kandanos 2'. These data agree with previous studies obtained from other almond cultivars, ranging from 14 to $23 \mathrm{mg} / 100 \mathrm{~g}$ $\mathrm{FW}^{3}$. 'Ferragnes', which is a widely cultivated cultivar, which contained relatively low protein content

Table I. ICP-AES instrumental operating condition.

\begin{tabular}{ll} 
Inductively coupled plasma & Perkin-Elmer, Optima 2100 \\
Operating power (W) & 1300 \\
Radiofrequency (MHz) & 40 \\
Coolant stream flow $(1 / \mathrm{min})$ & 3.785 \\
Torch type & Quartz torch with $2.0 \mathrm{~mm}$ \\
& i.d. injector tube \\
Nebulizer type & Crossflow \\
Nebulizer flow $(\mathrm{ml} / \mathrm{min})$ & 0.8 \\
Auxiliary flow $(\mathrm{ml} / \mathrm{min})$ & Co 9.2 nent citer ce document \\
Flow rate (ml $/ \mathrm{min})$ (Auteur de corresh50dance), Pantelidis, G \\
\hline
\end{tabular}

(11.4 mg/100 g FW) confirming the results reported by Cordeiro et al. (2001), when 12 Portuguese varieties were compared.

The most abundant minerals were $\mathrm{K}$ and $\mathrm{P}$, followed by $\mathrm{Ca}$ and $\mathrm{Mg}$. Similarly, in previous studies the nutrients present in high amounts in the kernel of almonds were $\mathrm{K}, \mathrm{P}, \mathrm{Mg}, \mathrm{S}$ and $\mathrm{Ca}$, and minor or trace elements are $\mathrm{Na}, \mathrm{Fe}, \mathrm{Cu}$ and $\mathrm{Mn}$ (Saura-Calixto and Cañellas 1982; Prats-Moya et al. 1997; Ayadi et al. 2006). Potassium content predominates with values ranging from 465 to $1235 \mathrm{mg} / 100 \mathrm{~g}$ dry weight (DW). Other values of $\mathrm{K}$ content in almond kernels from the literature varied from 390 to $940 \mathrm{mg} / 100 \mathrm{~g}$ in cultivars cultivated in Spain (Saura-Calixto et al. 1981; SauraCalixto and Cañellas 1982; Prats-Moya et al. 1997), Tunisia (Ayadi et al. 2006) and Italy, where similar values for 'Ferragnes', 'Lauranne' and 'Tuono' were shown (Piscopo et al. 2010). In this study, only $7 \%$ of the samples studied had $\mathrm{K}$ content greater than $958 \mathrm{mg} / 100 \mathrm{~g}$, and greatest values were found in the four almond accessions from Italy ('46D', '57D', '41D' and '72A').

Phosphorus content fluctuated from 119 to $748 \mathrm{mg} / 100 \mathrm{~g}$ DW, with greatest values being in the 'Bar vet 11 09-742', and 'Siatista 3' and 'Siatista 4'. The distribution of $p$ values was normal with a skew value of only 0.060 . Results herein reported agree with other published data on almond, as cultivars cultivated in Spain were in the range of $360-1050 \mathrm{mg} / 100 \mathrm{~g}$ (Saura-Calixto et al. 1981; Saura-Calixto and Cañellas 1982; Prats-Moya et al. 1997), in Tunisia 200$250 \mathrm{mg} / 100 \mathrm{~g}$ (Ayadi et al. 2006) and in California $440-510 \mathrm{mg} / 100 \mathrm{~g}$ (Hall et al. 1958).

Calcium content ranged from 160.0 to $663.0 \mathrm{mg} / 100 \mathrm{~g}$ DW. The $7 \%$ of samples had values greater than $485 \mathrm{mg} / 100 \mathrm{~g} \mathrm{DW}$, and greatest values were found in 'Truoito', 'Bar vet 4 09-736', 'Siatista 1', 'Drepanoto' and 'Lauranne'. Similar values were reported in studies in Spain (Saura-Calixto et al. 1981; Saura-Calixto and Cañellas 1982; Riquelme et al. 1985) and California (Hall 1958), while greater values were found in samples from Tunisia (390$1300 \mathrm{mg} / 100 \mathrm{~g} \mathrm{DW}$ ) (Ayadi et al. 2006). Piscopo et al. (2010) found considerably lower values of $\mathrm{Ca}$ in 11 almond cultivars grown in Italy, including cultivars 'Ferragnes', 'Lauranne' and 'Tuono', with the values ranging from 90 to $176 \mathrm{mg} / 100 \mathrm{~g}$ DW.

Magnesium content ranged from 100 to $333 \mathrm{mg} / 100 \mathrm{~g}$ DW, with greatest values found in the 'Bar vet 11 09-742', 'Bar pep 19 09-756' and 'Siatista 4'. In the literature, $\mathrm{Mg}$ content was found in the range of $154-276 \mathrm{mg} / 100 \mathrm{~g}$ DW in Italy (Piscopo et al. 2010), $90-180 \mathrm{mg} / 100 \mathrm{~g}$ in Tunisia (Ayadi et al. 2006) and $230-610 \mathrm{mg} / 100 \mathrm{~g}$ in Spain (Saura-Calixto et al. 1981; Saura-Calixto and Cañellas 1982; Prats-Moya et al. 1997).

With regard to nutritional aspects, percentage of recommended dietary allowances (RDA) or adequate intakes (AI) for those minerals for adult males (aged 19-50 years) was calculated. The RDA or AI for the 


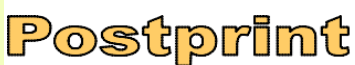

Version définitive du manuscrit publiée dans / Final version of the manuscript published in :

International Journal of Food Sciences and Nutrition (2012), Vol. 64, N.2, p. 202-209

DOI: 10.3109/09637486.2012.728202

Journal homepage: http://informahealthcare.com

Table II. Protein (g/100 g FW), potassium, phosphorus, calcium and magnesium (mg/100 g DW) contents in 72 almond genotypes from France, Greece and Italy. Values are means of years 2008 and 2009 for 30 samples, or only the year 2009.

\begin{tabular}{|c|c|c|c|c|c|c|c|}
\hline No. & Source $^{\mathrm{a}}$ & & Protein & Potassium & Phosphorus & Calcium & Magnesium \\
\hline 1 & FR & Ferraduel & 20 & 751 & 544 & 452 & 236 \\
\hline 2 & FR & Ferragnes & 11 & 810 & 572 & 496 & 239 \\
\hline 3 & FR & Ferrastar & 15 & 789 & 471 & 451 & 250 \\
\hline 4 & FR & Lauranne & 17 & 811 & 632 & 542 & 283 \\
\hline 5 & GR-north & Alkion & 17 & 566 & 415 & 324 & 172 \\
\hline 6 & GR-north & Drepanoto & 22 & 681 & 521 & 561 & 240 \\
\hline 7 & GR-north & Opsimanthis Volou & 19 & 881 & 681 & 481 & 260 \\
\hline 8 & GR-north & Rachia & 18 & 681 & 581 & 481 & 241 \\
\hline 9 & GR-north & Raptopoulou & 16 & 768 & 546 & 321 & 243 \\
\hline 10 & GR-north & Sfendami & 11 & 822 & 671 & 321 & 241 \\
\hline 11 & GR-north & Siatista 1 & 10 & 561 & 661 & 581 & 220 \\
\hline 12 & GR-north & Siatista 2 & 13 & 708 & 677 & 243 & 253 \\
\hline 13 & GR-north & Siatista 3 & 24 & 663 & 713 & 261 & 271 \\
\hline 14 & GR-north & Siatista 4 & 29 & 641 & 721 & 241 & 291 \\
\hline 15 & GR-north & Truoito & 26 & 844 & 603 & 663 & 261 \\
\hline 16 & GR-central & Afrata Chiou & 20 & 666 & 472 & 447 & 241 \\
\hline 17 & GR-central & Babatsiko & 23 & 813 & 614 & 244 & 257 \\
\hline 18 & GR-central & Bellou & 18 & 689 & 603 & 242 & 218 \\
\hline 19 & GR-central & Retsou & 21 & 510 & 355 & 458 & 238 \\
\hline 20 & GR-south & Athalia & 19 & 499 & 401 & 466 & 241 \\
\hline 21 & GR-south & Kandanos 1 & 22 & 570 & 318 & 345 & 159 \\
\hline 22 & GR-south & Kandanos 2 & 23 & 544 & 344 & 304 & 167 \\
\hline 23 & GR-south & Kandanos 3 & 22 & 624 & 468 & 484 & 257 \\
\hline 24 & GR-south & Kandanos 4 & 22 & 558 & 470 & 368 & 232 \\
\hline 25 & GR-south & Lakoniotika & 17 & 506 & 340 & 441 & 177 \\
\hline 26 & GR-south & Sitia 2 & 20 & 701 & 505 & 391 & 159 \\
\hline 27 & GR-south & Sitia 3 & 19 & 574 & 321 & 345 & 167 \\
\hline 28 & GR-south & Stone almond & 21 & 587 & 463 & 383 & 257 \\
\hline 29 & GR-south & Temen 1 & 24 & 652 & 480 & 456 & 232 \\
\hline 30 & IT-Bari & Cristomorto & 17 & 644 & 469 & 256 & 195 \\
\hline 31 & IT-Bari & Ferrante & 24 & 846 & 601 & 302 & 214 \\
\hline 32 & IT-Bari & Filippo Ceo & 18 & 691 & 416 & 243 & 180 \\
\hline 33 & IT-Bari & Fragiulio & 22 & 666 & 351 & 341 & 173 \\
\hline 34 & IT-Bari & Gaglano & 20 & 690 & 491 & 213 & 188 \\
\hline 35 & IT-Bari & Giunco di Cozze & 20 & 779 & 395 & 300 & 162 \\
\hline 36 & IT-Bari & Montrone & 22 & 683 & 310 & 322 & 174 \\
\hline 37 & IT-Bari & Riviezzo & 19 & 714 & 448 & 373 & 230 \\
\hline 38 & IT-Bari & Santore & 23 & 657 & 474 & 318 & 200 \\
\hline 39 & IT-Bari & Semziarte & 23 & 771 & 594 & 332 & 248 \\
\hline 40 & IT-Bari & Tenente & 17 & 740 & 411 & 215 & 166 \\
\hline 41 & IT-Bari & Tuono & 21 & 664 & 493 & 333 & 211 \\
\hline 42 & IT-Abruzzo & 119 D6 & 21 & 751 & 500 & 334 & 256 \\
\hline 43 & IT-Abruzzo & $14 \mathrm{~A} 80$ & 22 & 688 & 570 & 206 & 242 \\
\hline 44 & IT-Abruzzo & $15 \mathrm{~A}$ & 21 & 732 & 423 & 463 & 210 \\
\hline 45 & IT-Abruzzo & $16 \mathrm{~A}$ & 22 & 701 & 511 & 209 & 211 \\
\hline 46 & IT-Abruzzo & $18 \mathrm{D}$ & 25 & 789 & 529 & 311 & 256 \\
\hline 47 & IT-Abruzzo & 1A BIS & 20 & 789 & 413 & 293 & 246 \\
\hline 48 & IT-Abruzzo & $21 \mathrm{~A}$ & 22 & 488 & 443 & 457 & 214 \\
\hline 49 & IT-Abruzzo & $41 \mathrm{D}$ & 23 & 959 & 521 & 291 & 239 \\
\hline 50 & IT-Abruzzo & $46 \mathrm{D}$ & 20 & 1235 & 488 & 317 & 211 \\
\hline 51 & IT-Abruzzo & $50 \mathrm{D}$ & 17 & 607 & 447 & 323 & 220 \\
\hline 52 & IT-Abruzzo & $54 \mathrm{~A}$ & 22 & 691 & 480 & 365 & 232 \\
\hline 53 & IT-Abruzzo & $57 \mathrm{D}$ & 24 & 1102 & 647 & 260 & 258 \\
\hline 54 & IT-Abruzzo & $71 \mathrm{D}$ & 18 & 753 & 460 & 417 & 270 \\
\hline 55 & IT-Abruzzo & $72 \mathrm{~A}$ & 23 & 905 & 465 & 252 & 213 \\
\hline 56 & IT-Abruzzo & 740 & 18 & 692 & 390 & 399 & 247 \\
\hline 57 & IT-Abruzzo & Bar att $109-725$ & 21 & 721 & 631 & 160 & 260 \\
\hline 58 & IT-Abruzzo & Bar att 3 09-727 & 20 & 465 & 526 & 208 & 233 \\
\hline 59 & IT-Abruzzo & Bar att 6 09-730 & 18 & 561 & 521 & 247 & 251 \\
\hline 60 & IT-Abruzzo & Bar att $709-731$ & 21 & 643 & 552 & 221 & 271 \\
\hline 61 & IT-Abruzzo & Bar pep 19 09-756 & 24 & 621 & 581 & 220 & 321 \\
\hline 62 & IT-Abruzzo & Bar vet $109-734$ & 25 & 607 & 597 & 485 & 273 \\
\hline 63 & IT-Abruzzo & Bar vet $1009-741$ & 17 & 521 & 621 & 220 & 260 \\
\hline 64 & IT-Abruzzo & Bar vet $1109-742$ & 20 & 688 & 748 & 364 & 334 \\
\hline $65^{r c}$ & IT-Abruzzo & Bar vet $209-735$ & 18 & 641 & $671^{r g}$ & 341 & 271 \\
\hline
\end{tabular}




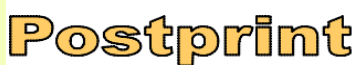

Version définitive du manuscrit publiée dans / Final version of the manuscript published in :

International Journal of Food Sciences and Nutrition (2012), Vol. 64, $\mathbf{N}^{\circ} .2$, p. 202-209

DOI: 10.3109/09637486.2012.728202

Journal homepage: http://informahealthcare.com

Table II - continued

\begin{tabular}{|c|c|c|c|c|c|c|c|}
\hline No. & Source ${ }^{a}$ & & Protein & Potassium & Phosphorus & Calcium & Magnesium \\
\hline 66 & IT-Abruzzo & Bar vet $409-736$ & 17 & 607 & 607 & 586 & 283 \\
\hline 67 & IT-Abruzzo & Bar vet 5 09-737 & 21 & 890 & 688 & 188 & 283 \\
\hline 68 & IT-Abruzzo & Forme $109-715$ & 22 & 721 & 611 & 234 & 231 \\
\hline 69 & IT-Abruzzo & Forme $1109-724$ & 17 & 521 & 501 & 300 & 220 \\
\hline 70 & IT-Abruzzo & Forme 6 09-720 & 17 & 581 & 621 & 340 & 250 \\
\hline 71 & IT-Abruzzo & Forme 7 09-721 & 16 & 623 & 542 & 221 & 271 \\
\hline 72 & IT-Abruzzo & Forme 8 09-722 & 18 & 502 & 432 & 362 & 281 \\
\hline \multicolumn{3}{|c|}{ Mean (range) } & $20.0(10-29)$ & $691(465-1235)$ & $518(310-748)$ & $345(160-663)$ & $236(159-334)$ \\
\hline \multicolumn{3}{|c|}{$F(p<0.001)$} & 8.2 & 6.5 & 6.4 & 10.5 & 6.4 \\
\hline \multicolumn{3}{|c|}{ LSD } & 3.8 & 164.3 & 139.5 & 107.0 & 49.1 \\
\hline \multicolumn{3}{|c|}{$\%$ significant differences ${ }^{\mathrm{b}}$} & $48.6 \%$ & $40.5 \%$ & $44.0 \%$ & $55.3 \%$ & $39.7 \%$ \\
\hline \multicolumn{3}{|c|}{$\mathrm{CV}(\%)$ among genotypes } & 17.1 & 19.6 & 20.5 & 31.5 & 15.6 \\
\hline
\end{tabular}

${ }^{a}$ FR, France; GR, Greece; IT, Italy; ${ }^{b}$ Percent significant differences at $p<0.050=(N / M) \times 100$, where $N$ is the number of significant differences found when samples were compared in pairs and $M$ is the maximum number of significant differences that can be found.

USA and Canadian adult males (aged 19-50 years) for protein are $56 \mathrm{~g} /$ day, $\mathrm{K} 4700 \mathrm{mg} /$ day, $\mathrm{P}$ $700 \mathrm{mg} /$ day, calcium $1000 \mathrm{mg} /$ day and magnesium $400-420 \mathrm{mg} /$ day (Institute of Medicine 1999; Institute of Medicine 2004). Consuming the recommended daily amount of $28.3 \mathrm{~g}(1 \mathrm{oz})$ of almond for different genotypes supplies $6-17 \%$ of protein, $3-7 \%$ of $\mathrm{K}, 12-29 \%$ of $\mathrm{P}, 4-18 \%$ of $\mathrm{Ca}$ and $11-22 \%$ of $\mathrm{Mg}$ of the RDA or AI for adults. The great variations found above strengthen the importance of selecting almond cultivars characterized by high nutritional contents.

Results from the one-way ANOVA showed that $\mathrm{Ca}$, followed by protein, had the greatest $F$ value (Ca, 11 ;

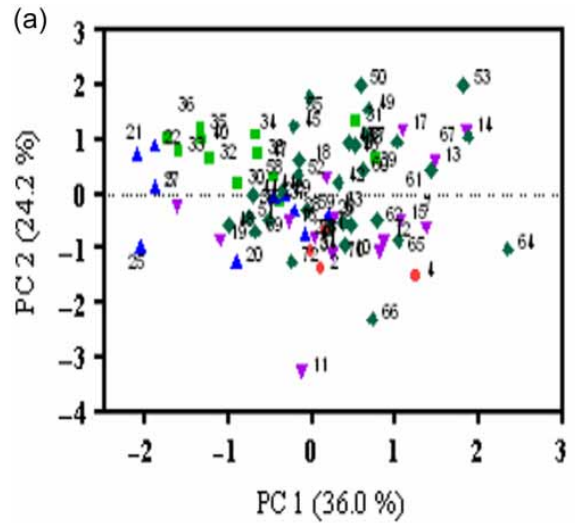

- France + Italy(Bari) - Italy(Abnzzo)
A Greece (south) v Greece (central-north)

\begin{tabular}{lcc}
\hline Character & PC1 & PC2 \\
\hline Protein & 0.162 & 0.651 \\
$\mathrm{~K}$ & 0.458 & 0.480 \\
$\mathrm{P}$ & 0.910 & -0.130 \\
$\mathrm{Ca}$ & -0.073 & -0.671 \\
$\mathrm{Mg}$ & 0.854 & -0.299 \\
\hline
\end{tabular}

protein, $8 ; \mathrm{K}, \mathrm{P}$ and $\mathrm{Mg}, 6)$ and percentage of samples with significant differences (Ca, 55\%; protein, $49 \%$; $\mathrm{K}, \mathrm{P}$ and $\mathrm{Mg}, 40-44 \%$ ) (Table II). Moreover, the variation coefficient among almond genotypes was greatest for $\mathrm{Ca}(\mathrm{Ca}, 32 \%$; protein, $\mathrm{K}, \mathrm{P}$ and $\mathrm{Mg}, 16-$ $21 \%)$. The above results suggest that nutrients such as $\mathrm{Ca}$, followed by the protein content, could be used to mark differences among cultivars, since they exhibited the greatest variability in the studied almond genotypes. Similar results were reported for $\mathrm{Ca}$ when compared with other 18 elements in almond in the study by Prats-Moya et al. (1997).

A significant positive correlation was found between $\mathrm{P}$ and $\mathrm{Mg}(r=0.697 ; p<0.001)$, and a weak (b)

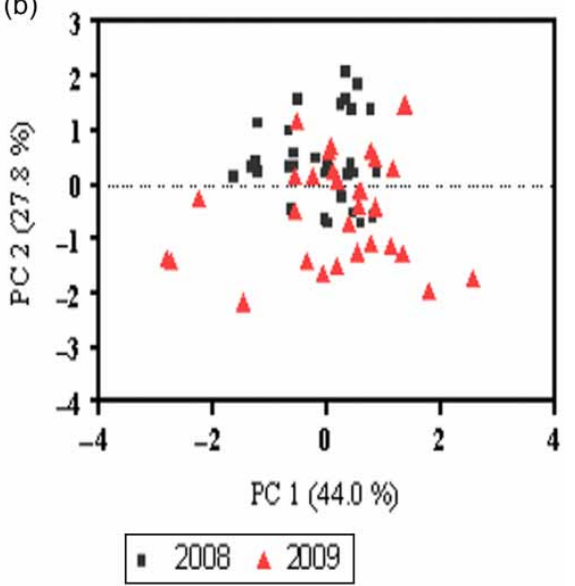

\begin{tabular}{lcr}
\hline Character & $\mathrm{PC1}$ & \multicolumn{1}{c}{$\mathrm{PC} 2$} \\
\hline Protein & -0.163 & 0.679 \\
$\mathrm{~K}$ & 0.551 & 0.578 \\
$\mathrm{P}$ & 0.912 & 0.190 \\
$\mathrm{Ca}$ & 0.459 & -0.757 \\
$\mathrm{Mg}$ & 0.915 & -0.037 \\
\hline
\end{tabular}

Figure 1. PCA plot and associated variables selected with factor loadings for the protein and mineral contents of (a) 72 almond kernels from France, Greece and Italy and (b) 30 almond genotypes, during years 2008 (squares) and 2009 (triangles). Numbers in PCA plot indicate the almond samples shown in Table II. 
Version définitive du manuscrit publiée dans / Final version of the manuscript published in :

International Journal of Food Sciences and Nutrition (2012), Vol. 64, $\mathbf{N}^{\circ}$.2, p. 202-209

DOI: 10.3109/JS£37430.2012.728202

\section{Journal homepage: http://informahealthcare.com}

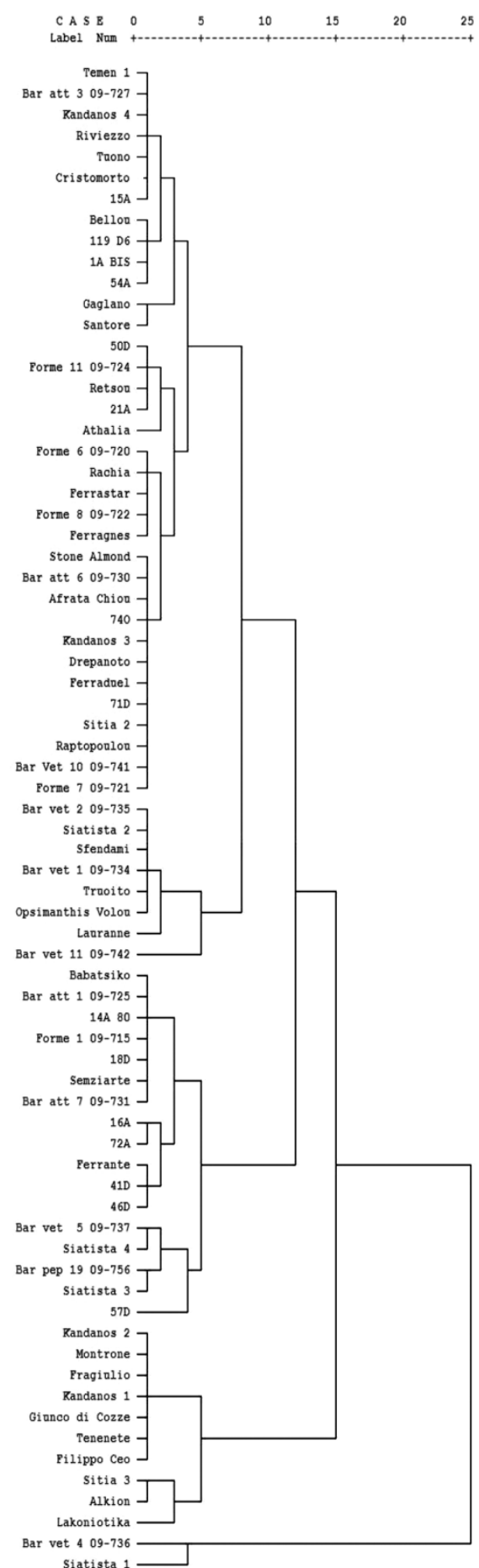

Figure 2. Cluster dendrogram of 72 almond cultivars and accessions.

correlation was found between $\mathrm{P}$ and $\mathrm{K}(r=0.278$; $p=0.018)$. The relationships among $\mathrm{K}, \mathrm{P}$ and $\mathrm{Mg}$ can also be detected from their similar variation coefficients and $F$ ratio when one-way ANOVA was applied, which differed from the greater values found for $\mathrm{Ca}$ (Table II). There was no other significant correlation found between the remaining studied parameters (data not shown). The strong correlation detected between $\mathrm{P}$ and $\mathrm{Mg}$ in the almond kernels may be due to the synergic effect of $\mathrm{P}$ on $\mathrm{Mg}$ accumulation in plants, which is associated with the ionic balance related to cation and anion uptake into plants (Mulder 1952). Similar correlations among the studied macronutrients were also found in almonds by Prats-Moya et al. (1997), whereas Schirra (1997) reported negative correlation between P and Ca contents, which was not found in this study.

Calcium content was greater than $\mathrm{Mg}$ in the majority of samples (increased between $20 \%$ and $164 \%$ in $71 \%$ of samples), and this may be related to their ionic forms having two positive electrical charges which make them antagonistic during root absorption. Calcium and $\mathrm{Mg}$ contents were similar in $25 \%$ of samples, whereas they had an inverse relationship (decrease $31-38 \%$ ) in only $4 \%$ of samples. An inverse relationship in the $\mathrm{Ca}$ and $\mathrm{Mg}$ contents was also reported in previous studies on almond (Saura-Calixto and Cañellas 1982; Cordeiro et al. 2001).

\section{PCA and clustering analysis}

PCA was used in order to establish the relationships and differentiation among the variables. Cluster linear analysis was also carried out to discover natural groupings of samples. PCA produced two components (PC1 and PC2) which accounted for a cumulative $60.2 \%$ of variation, and are presented as a scatter diagram in Figure 1. The parameters having an important correlation to PC1 (values >0.30) $(36.0 \%$ of variance) were $\mathrm{P}$ and $\mathrm{Mg}$ and to a lesser extent $\mathrm{K}$. In the second component (PC2) (24.2\% of variance), the protein and $\mathrm{K}$ had a positive correlation, while the $\mathrm{Ca}$ content had a negative correlation. The dendrogram shows five clusters at a distance value of 5 (Figure 2). The smallest cluster included 'Bar vet 4 09-736' and 'Siatista 1', which had low protein and high $\mathrm{Ca}$ contents. A sample with high $\mathrm{P}, \mathrm{Mg}, \mathrm{K}$ and protein contents (increased values in PC1 and PC2) was the '57D'. There was no clear distinction among the different origins of samples.

\section{Influence of harvesting year and growing region}

The harvesting year, growing region and cultivation methods would be expected to at least partially influence the nutrient composition of almonds, since minerals are obtained by the plant from the soil in which it grows, the water applied in production and growth is influenced by weather conditions. The study of variation in the measured traits due to harvest year showed that the lowest variability coefficient was that for protein (13\%). It increased in K (17\%), followed by $\mathrm{Mg}(19 \%), \mathrm{Ca}(24 \%)$ and P (27\%), which suggests that the protein content may be the most stable trait in relation to year variation (Table III). Considering that the protein content also had a relatively great variation among genotypes, it is suggested that it may be 
Version définitive du manuscrit publiée dans / Final version of the manuscript published in :

International Journal of Food Sciences and Nutrition (2012), Vol. 64, $\mathbf{N}^{\circ}$.2, p. 202-209

DOI: 10.3109/09637486.2012.728202

Journal homepage: http://informahealthcare.com

Table III. Coefficient variation CV(\%) for 30 samples harvested in both years 2008 and 2009.

\begin{tabular}{|c|c|c|c|c|c|c|}
\hline Source & Genotype & Protein & Potassium & Phosphorus & Calcium & Magnesium \\
\hline FR & Ferraduel & 1 & 6 & 12 & 34 & 3 \\
\hline FR & Ferragnes & 23 & 2 & 19 & 24 & 13 \\
\hline FR & Ferrastar & 18 & 4 & 22 & 17 & 13 \\
\hline FR & Lauranne & 24 & 1 & 23 & 37 & 14 \\
\hline GR-central & Afrata Chiou & 0 & 14 & 18 & 36 & 6 \\
\hline GR-central & Babatsiko & 6 & 1 & 22 & 23 & 14 \\
\hline GR-central & Bellou & 11 & 19 & 14 & 11 & 8 \\
\hline GR-central & Retsou & 8 & 3 & 18 & 26 & 7 \\
\hline GR-south & Athalia & 2 & 11 & 3 & 23 & 6 \\
\hline GR-south & Kandanos 1 & 15 & 87 & 82 & 4 & 48 \\
\hline GR-south & Kandanos 2 & 20 & 84 & 92 & 7 & 54 \\
\hline GR-south & Kandanos 3 & 23 & 18 & 8 & 6 & 2 \\
\hline GR-south & Kandanos 4 & 18 & 7 & 26 & 14 & 13 \\
\hline GR-south & Lakoniotika & 12 & 28 & 36 & 14 & 36 \\
\hline GR-south & Sitia 2 & 2 & 4 & 13 & 18 & 48 \\
\hline GR-south & Sitia 3 & 19 & 38 & 40 & 18 & 54 \\
\hline GR-south & Stone Almond & 0 & 0 & 4 & 45 & 2 \\
\hline GR-south & Temen 1 & 11 & 37 & 23 & 39 & 13 \\
\hline IT-Bari & Cristomorto & 1 & 10 & 36 & 48 & 27 \\
\hline IT-Bari & Ferrante & 6 & 14 & 10 & 37 & 5 \\
\hline IT-Bari & Filippo Ceo & 2 & 10 & 12 & 9 & 0 \\
\hline IT-Bari & Fragiulio & 7 & 10 & 56 & 17 & 55 \\
\hline IT-Bari & Gaglano & 23 & 6 & 6 & 23 & 9 \\
\hline IT-Bari & Giunco di Cozze & 20 & 25 & 53 & 1 & 51 \\
\hline IT-Bari & Montrone & 17 & 29 & 37 & 8 & 21 \\
\hline IT-Bari & Riviezzo & 11 & 7 & 25 & 35 & 8 \\
\hline IT-Bari & Santore & 2 & 11 & 18 & 29 & 16 \\
\hline IT-Bari & Semziarte & 3 & 13 & 19 & 38 & 7 \\
\hline IT-Bari & Tenente & 34 & 19 & 58 & 43 & 29 \\
\hline IT-Bari & Tuono & 7 & 1 & 18 & 48 & 14 \\
\hline \multicolumn{2}{|c|}{$\mathrm{CV}(\%)$ due to year } & 12.5 & 17.2 & 27.4 & 24.4 & 19.2 \\
\hline
\end{tabular}

indicative of differences among genotypes and almond origin identification.

In order to detect any possible effect of weather conditions on mineral nutrient and protein contents, PCA was applied to the mean values of measured traits of the 30 almond genotypes analysed during both years 2008 and 2009 (Figure 1b). The components produced by PCA were similar to those produced when all 72 genotypes were analysed (Figure 1a). Although there was not a clear separation between harvesting years, most values from the year 2009 were negative in the $Y$-axis which represent the PC2, suggesting that $\mathrm{Ca}$ contents tended to be greater in year 2009 compared to those in 2008.

In order to determine the impact of environment on almond nutrient contents, data from monitoring stations positioned nearby the experimental sampling points were collected during the 1st March until the 30th September in each harvesting year (Table IV). Greatest climatic differences between years were found in Nimes, France, compared with the other measured cites; the minimum, maximum and mean temperatures were greater by $1.1,2.8$ and $2.0^{\circ} \mathrm{C}$, respectively, in 2009 compared with those in 2008, whereas in other sites the mean temperature was decreased in 2009 compared with that in 2008 by $0.2-1^{\circ} \mathrm{C}$. Correlation analyses were carried out using data separated for each country during the two studied

Table IV. Observed weather conditions across the sites where almonds were sampled, between March and September in 2008 and 2009.

\begin{tabular}{|c|c|c|c|c|c|c|c|c|}
\hline & \multicolumn{6}{|c|}{ Temperature $\left({ }^{\circ} \mathrm{C}\right)$} & & \\
\hline & \multicolumn{2}{|c|}{ Av min } & \multicolumn{2}{|c|}{ Av max } & \multicolumn{2}{|c|}{ Mean } & \multicolumn{2}{|c|}{ Precipitation (mm) } \\
\hline & 2008 & 2009 & 2008 & 2009 & 2008 & 2009 & 2008 & 2009 \\
\hline France (Nîmes) & 12.7 & 13.8 & 23.5 & 26.3 & 18.1 & 20.1 & 496.6 & 342.8 \\
\hline Greece-north (Naoussa) & 14.1 & 14.6 & 26.0 & 25.0 & 20.0 & 19.8 & 287.5 & 329.0 \\
\hline Greece-central (Volos) & 22.3 & 21.5 & 27.3 & 26.2 & 24.8 & 23.8 & 257.2 & 140.0 \\
\hline Greece- south west Crete (Kandanos) & 15.4 & 14.6 & 24.8 & 23.6 & 20.1 & 19.1 & 148.6 & 162.4 \\
\hline Greece- south east Crete (Ierapetra) & 20.0 & 19.4 & 27.7 & 26.6 & 23.8 & 23.1 & 62.1 & 143.0 \\
\hline Italy (Bari) & 13.7 & 13.8 & 26.0 & 25.5 & 19.9 & 19.7 & 183.3 & 299.8 \\
\hline
\end{tabular}


years. In France, the mean temperature was positively correlated with $\mathrm{Ca}(r=0.893, p=0.003)$ and $\mathrm{P}(r=0.778, p=0.023)$, and precipitation was negatively correlated with $\mathrm{Ca} \quad(r=-0.893$, $p=0.003)$ and $\mathrm{P}(r=-0.778, p=0.023)$. There were no other significant correlation and strong correlation found between mineral nutrients, protein and climatic conditions, in the other sites studied, or when all experimental cites and climatic data were analysed (data not shown). The higher temperatures observed in 2009 in Nimes may have favoured growth and nutrient utilization, resulting in greater nutrient contents in almonds.

\section{Conclusions}

In this study, the mineral nutrient and protein contents were analysed in a relatively large number of almond accessions found in Greece, France and Italy. The results showed a great variation in the nutrient content and the amount of nutrient supplied when consuming the recommended daily amount of one serving of almond, which strengthens the importance of selecting cultivars with high nutrient content. The protein content was found to be the most appropriate parameter to use for marking differences among genotypes and for identifying the almond origin. Also, the almond mineral and protein contents depended on genotype rather than correlating with their origin.

\section{Acknowledgements}

P.D. and G.P. would like to thank P. Psoma for technical assistance.

Declaration of interest: This work was $50 \%$ funded by the European Commission, Directorate General for Agriculture and Rural Development, AGRI GEN RES Community Program (No. 870/2004) and 50\% by the authors' institutions. The authors report no conflicts of interest. The authors alone are responsible for the content and writing of the paper.

\section{References}

Ahrens S, Venkatachalam M, Mistry AM, Lapsley K, Sathe SK. 2005. Almond (Prunus dulcis L.) protein quality. Plant Foods Hum Nutr 60:123-128.

Albala K. 2009. Almonds along the silk road: the exchange and adaptation of ideas from West to East. Petits Propos Culinaires $88: 17-32$.

Association of Official Analytical Chemists (AOAC). 1995. Official Methods of Analysis. 16th ed., Arlington, VA: Association of Official Analytical Chemists.

Aslantas R, Gouleryouz M, Turan M. 2001. Some chemical contents of selected almond (Prunus lamygdalis 'Batsch) types.

D Cahiers Options (Méditerranéennes 56:3477+350. Pantelidis, G.
Ayadi M, Ghrab M, Gargouri K, Elloumi O, Zribi F, Ben Mimoun M, et al. 2006. Kernel characteristics of almond cultivars under rainfed conditions. Acta Hortic 726:377-381.

Champagne CM. 2008. Magnesium in hypertension, cardiovascular disease, metabolic syndrome, and other conditions: a review. Nutr Clin Pract 23:142-151.

Chen C-Y, Lapsley K, Blumberg J. 2006. Perspective. A nutrition and health perspective on almonds. J Sci Food Agric 86: 2245-2250.

Cordeiro V, Oliveira M, Ventura J, Monteiro A. 2001. Study of some physical characters and nutritive composition of the Portuguese's (local) almond varieties. Cahiers Options Méditerranéennes 56: 333-337.

García-López C, Grané-Teruel N, Berenguer-Navarro V, GarcíaGarcía JE, Martín-Carratalá ML. 1996. Major fatty acid composition of 19 almond cultivars of different origins. A chemometric approach. J Agric Food Chem 44:1751-1755.

Hall AP, Moore JG, Gunning B, Cook BB. 1958. The nutritive value of fresh and roasted. California-grown Nonpareil almonds. J Agric Food Chem 6:377-382.

Institute of Medicine. 1999. Dietary Reference Intakes for Calcium, Phosphorus, Magnesium, Vitamin D, and Fluoride. Washington, DC: National Academy Press.

Institute of Medicine. 2004. Dietary Reference Intakes for Water, Potassium, Sodium, Chloride, and Sulfate. Washington, DC: The National Academies Press.

Kumar K, Sharma SD. 2005. Self-compatible indigenous almond selections: characterizations and assessment. Acta Hortic 696: 65-67.

Mulder D. 1952. Nutritional studies on fruit trees II. The relation between potassium, magnesium and phosphorus in apple leaves. Plant Soil 4:107-117.

Piscopo A, Romeo FV, Petrovicova B, Poiana M. 2010. Effect of the harvest time on kernel quality of several almond varieties (Prunus dulcis (Mill.) D.A. Webb). Sci Hortic 125:41-46.

Prats-Moya S, Grané-Teruel N, Berenguer-Navarro V, MartínCarratalá ML. 1997. Inductively coupled plasma application for the classification of 19 almond cultivars using inorganic element composition. J Agric Food Chem 45:2093-2097.

Riquelme F, Romojaro F, Giménez JL, Llorente S. 1985. Study on protein fraction in some almonds varieties of the Spanish southeast. Fruit Sci Rep 12:55-59.

Ros E. 2010. Review: health benefits of nut consumption. Nutrients 2:652-682.

Ruggeri S, Cappelloni M, Gambelli L, Nicoli S, Carnovale E. 1998. Chemical composition and nutritive value of nuts grown in Italy. Ital J Food Sci 10:243-252.

Saura-Calixto F, Bauza M, Martinez de Toda F, Argamenteria A. 1981. Amino acids, sugars and inorganic elements in the sweet almond (Prunus amygdalus). J Agric Food Chem 29: $509-511$.

Saura-Calixto F, Cañellas J. 1982. Mineral composition of almond varieties (Prunus amygdalus). Z Lebensm Unters Forsch 174: $129-131$.

Schirra M. 1997. Postharvest technology and utilization of almonds. Hort Rev 20:267-292.

USDA Nutrient Laboratory Database. Release 16, 2005. Available at http://www.pcna.net/images/pdf/8B_Nutrient_Content_of_ Tree_Nuts.pdf. Accessed on 15 June 2012.

Venkatachalam M, Sathe SK. 2006. Chemical composition of selected edible nut seeds. J Agric Food Chem 54:4705-4714.

Yada S, Lapsley K, Huang G. 2011. A review of composition studies of cultivated almonds: macronutrients and micronutrients. BacclJfFood Compos Anal 24:469-480. 